\title{
MORDECAI CUBITT COOKE.
}

\author{
(1825-1914.) \\ By I. Ramsbottom, M.A.†
}

Mordecai Cubitt Cooke was born at Horning, Norfolk, on July I 2th, I825. His father, Mordecai Cooke, had been a middleman in the bombasine trade, but when the manufacture of this material declined he started a shop (now the village post-office), which, being the only one in the district, dealt in everything needed by a rural population. "This was the domestic era of the tinder box and rushlight, and before the first boxes of 'Lucifers' astonished the natives at the cost of twopence halfpenny each." " He was a strong Calvinist and frequently conducted prayer meetings. His wife, Mary Cubitt, was the daughter of the master of a school at the neighbouring village of Neatishead. Cooke's christian names have always been a matter of interest, and that he himself perhaps felt a little strongly on the subject is seen from the preface to his first book "The Seven Sisters of Sleep." Mordecai is a family name, and there is a tradition that some time in the $15^{\text {th }}$ century the Cooke of that day married a Jewess who gave her children the names Mordecai and Rebecca: in any case the names can be traced back to the middle of the 17 th century. As a child Cooke contracted smallpox, which left him temporarily blind, and until the age of twelve he had much trouble with his eyes. His first school was a dame's school, which he attended until he was nine years of age; the dame was assisted by a niece who was an excellent penwoman, and it was to her tuition that Cooke owed the bold flowing hand so familiar to mycologists. In this connection it is a matter of surprise that Cooke wrote exceedingly rapidly, laying the sheets in front of him to dry while still writing, making few alterations, and doing remarkably little editing. It was to his mother that Cooke owed his introduction to botany, for as a child he collected flowers with her in the Norfolk lanes. His earliest book was Culpepper, which probably belonged to her, as it is

+ A shortened form of this obituary notice appeared in the Journal of Botany, Vol. 53, p. $5^{8}$ (1915).

* Essex Naturalist X., p. 216 (1897). 
inscribed "M. Cook. I 827." In I834 he left the dame's school and was sent to Ilford (on the top of a stage coach) to be educated by his uncle, the Rev. James Cubitt, a dissenting minister, who afterwards became classical tutor at Spurgeon's College. "I was with my uncle for two years, and during that time was laid the foundation of every quality I was able to display in the way of work in after life. My uncle grounded me well in the rudiments of Latin, Greek, Algebra, etc., and he even made my daily walks contributary to the acquisition of useful knowledge, for he used to send me down the Barking road with instructions to make collections of plants and flowers that grew by the wayside and to name them afterwards with such assistance as I could get from him or his little botanical library." In a presidential address to the Hackney Microscopical and Natural History Society in 1887 Cooke referred to this period: "This Jubilee year of Her Majesty's reign reminds me that I began the study of Botany before that reign commenced. ... I cannot say that I proceeded very far in the study of plants during the reign of William IV., but I was in the habit of going periodically into the lanes and fields to collect flowers, and on my return home, did my best, by pulling them in pieces, with Macgillivray's edition of Withering's Botany before me, as my only guide, to discover their names and places. It was dry work in those days, and all the methods were of the driest and most mechanical." Pinnock's Catechism was almost the only other book within reach of poor country students, and a clergyman's daughter who could "run down" a hundred plants from Withering gained quite a local reputation. It would seem that Cooke remained with his uncle four years, as they removed to Stratford-on-Avon and he there remembered witnessing the proclamation of the accession of Queen Victoria. Shortly afterwards Cubitt married, and in 1838 Cooke returned to Norfolk and was sent along with his brother, who still lives, to a school at Neatishead, kept by one William Moore. His education here was peculiar. He already knew all that Moore found it necessary to teach his pupils. Moore, however, in addition to pedagogy did land surveying, and Cooke accompanied him, helped with the practical part of the work, and then worked out the results during school hours. Moore, moreover, kept the Rates book for the overseers of the parish, and his useful pupil was permitted to assist further in working out the rates.

At the age of fifteen Cooke was apprenticed to a wholesale linen and drapery establishment at Norwich. The drapery business apparently. suited him but little, the only pleasure he 
seemed to get out of his existence was by learning to play on wind instruments, on most of which he became more or less proficient. At the age of twenty he left Norfolk and returned to London to live with a second uncle, William Cubitt, a keen Baptist and one of the compilers of the Baptist Year Book, by trade a manufacturer of sealette, velvet and coach trimmings. Cooke found occupation as a copying clerk in a solicitor's office, but in 1847 had a serious attack of gastritis and lost his situation. About this time he had begun to blossom out as a poet, for we find him publishing; at $4 \frac{1}{2} \mathrm{~d}$. each, verse with such titles as "The Struggle for Freedom," "Flight of Thought," "Course of Love," etc. He seems to have tried his hand as a lawyer's clerk in the bankruptcy court, as an usher in a school at Birmingham, and as a lecturer on poets and poetry. About this time came Cooke's introduction to fungi. "It was my good fortune to be introduced to an East Anglian gentleman,* who resided in a small agricultural village not ten miles from Norwich. I had been invited to give a gossiping lecture to the rustics in the schoolroom, and was asked to take a preliminary tea with the squire. It soon became manifest that the hobby of my host was 'edible fungi,' a subject of which I was then profoundly ignorant, but I became greatly interested in the discovery that there were other fungi beside the mushroom which might be eaten, and I had the pleasure of looking over his portfolio of coloured drawings, and hearing his explanations and encomiums. This was my first inspiration to turn my attention to 'toad-stools.' I had never seen them before, or at least with an appreciative eye, and the subject came upon me as a revelation. At first I did, as so many others have done, restricted my interest to their edible qualities, and had no ambition beyond being able to recognize, collect, and devour some half-dozen different kinds of 'toad-stools,' which, in all my surroundings, I had been taught to regard as 'rank pi'sen.' Since that eventful evening I have never abandoned the pursuit, and it has been my solace." +

In I 849 we find Cooke editing " The Monthly Repository of General Literature," though it may be added that he wrote practically the whole of this short-lived periodical under various names or permutation and combinations of his initials. At the end of this year he accepted an invitation from an aunt and uncle at Stockton-on-Tees to make himself acquainted with the Pestalozzian system of educating infants. He remained at the school for three months and then successfully replied to an advertisement for a master to open the new Trinity School, Lambeth, under

\footnotetext{
* Richard Ward, Salhouse Hall.

† Grevillea XIX., p. 68 (1891).
} 
the old National School system. Cooke now settled downi, and applied himself with his customary vigour to his occupation. In addition to his ordinary teaching he held evening classes on all kinds of subjects and wrote for educational journals on practically everything. In connection with the school he began a museum of economic products and conducted a similar museum for the Metropolitan Scholastic Association of elementary teachers: he also gave lessons on economic botany, led thereto principally by the writings of Peter Lunn Simmonds, author of Commercial Products of Vegetable Kingdom. One branch of this study related to Indian food products, of which he acquired a fairly good general knowledge. He used to visit brokers in Mark Lane and Mincing Lane for the purpose of obtaining samples of any new or interesting products which came into the market. He entered as a student in the Science and Art Department at South Kensington, where he studied various subjects, including structural and systematic botany and drawing. About this time he made a fine series of water colour studies of birds. Subsequently he conducted botanical classes under the Science and Art Department of which he was the first certificated teacher under the Minutes.

In 1860 another clergyman was appointed to Trinity Church who considered Cooke's evening lectures on various subjects unnecessary and his botanical activities mere waste of time. In consequence Cooke resigned his post, and sold his museum for $£ \mathrm{I} 00$. This same year he published his first volume, The Seven Sisters of Sleep, a popular history of the prevailing narcotics of the world, a theme suggested by his collections. About this time he was connected with Twining's Economic Museum, Twickenham, and also gave botanical lectures in the gardens of Holly Lodge, Highgate, to the gardeners and others in the employ of Baroness Burdett-Coutts, and at the Working Men's College.

After leaving Lambeth, Cooke shared rooms with P. L. Simmonds, for whom he wrote in the Technologist. In 1861 he was, on the recommendation of Simmonds, employed to compile the catalogue of the Indian exhibits at the second great English Exhibition of I 862 . Here he got to know Dr. Forbes Watson, chief of the India Museum, and, after completing a similar work for the commissioners, he was taken over as a sort of handy man at the Museum, Fife House, Whitehall, where he arranged and stored the raw products of India. $\mathrm{He}$ remained until the Museum was abolished in $\mathrm{I} 880$.

When conducting his botanical classes in the late fifties, Cooke sometimes took his pupils for country rambles in order to give them practical demonstrations on wild flowers. Subse- 
quently some of these old pupils, who were joined by outsiders, constituted themselves into a small society. This, "The Society of Amateur Botanists," was founded in 1862 . It was "established for mutual assistance in the study of British Plants, by organised Excursions into the country-the interchange of Specimens-the communication of Papers-and the establishment of a Library, Herbarium, and Museum, or such other means as may from time to time be deemed expedient." Cooke was the first and only president. Excursions were neld during the summer on alternate Saturday afternoons, and fortnightly meetings on Wednesday evenings. The excursions were the chief attraction "for collecting plants, and for a cosy tea afterwards." "It was while engaged in these excursions that I first became interested in fungus parasites." According to Mr. W. G. Smith," "Dr. Cooke at that time had noticed the fungi but little; he collected and studied the microfungi and was very keen on all animate subjects. He captured toads, frogs, newts and snakes." To add to the picture - "Dr. Cooke was an inveterate smoker, and when he was not pulling at his pipe he was singing." The Society attracted other botanists and at one time numbered about fifty members. Some of the papers read at the meetings were published in the Journal of Botany or in the ephemeral Botanist's Chronicle. Among the better known botanists who were members, or attended some of the meetings, were Messrs. J. Britten, W. T. T. Dyer, W. W. Newbould, B. Seeman, W. G. Smith, and H. Trimen. The meetings were first held at the Metropolitan Club in Euston Road, but afterwards in the room over Robert Hardwicke's shop in Piccadilly. W. G. Smith engraved a brass plate "Society of Amateur Botanists," which was placed on the side of Hardwicke's door. About this time Hardwicke was a successful publisher of Natural History books, e.g., the third edition of English Botany, with Boswell Syme as editor and with Mrs. Edwin Lankester as responsible for the popular notes. He was also publishing the Popular Science Review. Dr. Edwin Lankester introduced Cooke to Hardwicke. "As contributor to the pages of the Popular Science Review and as a writer of popular books on Natural History, of which Mr. Hardwicke was the publisher, I was in close business relations with Mr. Hardwicke. . . . At length I suggested to Mr. Hardwicke and to Mr. Ketteringham [his manager] that there was a good opening for a cheap monthly magazine, which should be devoted to Natural History and Microscopy, offering facilities for exchanges and copious notes and queries. This idea was eagerly entertained, and Hardwicke's Science Gossip was the title suggested by $\mathrm{Mr}$. Hardwicke, and to this he adhered

* Gard. Chron. p. 356 (1914, II.). 
pertinaciously. At length the scheme took form, and I was selected to model and afterwards act as Editor of the new Journal. The first number appeared January ist, I865, and became at once a success. At that time there was no competitor, and for a long time it was the only cheap Journal of Natural History."* It is interesting to note that Cooke favoured the more poetical title of Veil of Isis for the new magazine, and the symbol of the goddess appeared at the end of the preface. Cooke's versatility here found full scope, and the paper achieved a "decided success even beyond our most sanguine hopes when we first planned its constitution." In the May issue of the first volume there appeared a letter from $W$. Gibson suggesting the formation of an association of amateur microscopists which would be of greater service to them than the older and more pretentious Royal Microscopical Society, something " on the plan of the Society of Amateur Botanists." The Editor added a note: "We insert our correspondent's communication, and would be glad to hear from any microscopists desircus of co-operating with him in carrying out his proposals," and solicited communications on the subject. The suggestion fell on fertile ground. Two of the members of the Amateur Botanists were $T$. Ketteringham and W. M. Bywater, who was manager of a saddlery business house in Hanover Square. Both were keen microscopists and rather musical. They used to meet once a week and Cooke was introduced to the meetings by Ketteringham. Over the shop in Hanover Square the three, for the first hour or so, talked microscopy, and from ten to eleven discussed cigars, sandwiches, liquid refreshment and science gossip. After the publication of Gibson's letter, he was invited to one of the meetıngs, and " all of us resolved to make a strong effort for the establishment of such a society as that proposed." Hardwicke, though not a microscopist, did all he could by placing his office at their disposal for preliminary meetings and allowing it to be used as a provisional office for correspondence. After several meetings, at which Cooke was chairman, the "Quekett Microscopical Club" was formed. Cooke was asked to be the first president, but declined in the event of the committee being able to secure the services of Dr. Edwin Lankester (which they did) or someone of. equal repute or influence. Cooke was one of the two vice-presidents during the first year, and Hardwicke treasurer and secretary. The first paper in the first volume of the journal of the club is by Cooke, "On Universal Microscopic Admeasurement." He pointed out the advisability of the universal adoption of the French metric system for microscopic measurement instead of the various systems then in

* Journ. Quekett Mieros. Club, ser. 2 VII., p. 229 (1899). 
vogue. Convinced by his sensible arguments, this young society adopted his suggestion and appointed him Honorary Secretary for Foreign Correspondence, to the end that he might correspond by circular with the other then known microscopical societies. Cooke deserves the gratitude of every user of the microscope in this county for his successful efforts. The Quekett admitted 155 members during its first year. The excursions of the Society of Amateur Botanists - "the only instance, at that period of time in which any periodical excursions were made by any society in or around London "-were copied. Many of the Amateur Botanists joined the club " and always declared that the newer and larger society with a wider programme had extinguished them."

During this period Cooke was energetic in other directions. While working for his Science and Art examinations he "realised the need for some simple text book on botany for students," and this led him to write his Manual of Structural Botany, a small shilling book which was published in $186 \mathrm{I}$ and was a great success and passed through numerous editions. In the following year a Manual of Botanic Terms was published. The preface tells us that "the Terms are written in their Anglicised forms, under which they are commonly employed; and the derivations are recovered from the mysticism of a Greek alphabet. Both these innovations, it is confidently hoped, will commend the work to such of the operative classes as are cultivating the study of Botany": also his first book on fungi-A Plain and Easy Account of British Fungi-illustrated by twenty coloured plates lithographed by Cooke's youngest brother, E. Cooke. Only the better known of the larger fungi are treated and methods of cooking the edible ones are given. This was the first book that treated fungi in a popular manner, and with the manuals seems to have grown out of Cooke's evening lectures- "Botanical classes established for Operatives."

Cooke now began to aspire to a real knowledge of fungi. He entered into correspondence with the two most eminent British mycologists of that date, M. J. Berkeley and C. E. Broome, and obtained their assistance in many ways. Several of his letters are retained in the Berkeley Correspondence and in the Broome Correspondence, both of which are preserved in the Botanical Department of the British Museum. His energy soon bore fruit, and in the first volume of the Journal of Botany (1863) he published a paper on "Rare or new hymenomycetal Fungi," with a coloured plate, and three papers on microfungi in the second volume. In 1863 appeared his Index Fungorum Britannicorum, a complete list of the fungi found in the British Isles to that date, arranged so as to be 
applicable either as a check-list or for herbarium labels. The "plain and easy" work continued. Several papers on microscopic fungi were written for the Popular Science Review during $1863-4$, and these were revised and expanded to comprise the well-known Rust, Smut, Mildew and Mould: this introduction to the study of microscopic fungi, which was illustrated by J. E. Sowerby, is still used, and is probably the best of Cooke's popular books. Another useful book was his "Easy Guide" to the Hepaticae, reprinted from the first volume of Science Gossip, with which it had been issued. In 1867 he published his not very satisfactory Fern Book for Everybody. In 1869 we find Cooke writing to Broome that he thought of preparing a handbook to the British fungi at his own risk : and in 1870 his largest undertaking was hinted at when he writes: "I am going in very extensively for these drawings in the hope of publishing an Atlas to my 'Handbook.'" The Handbook of British Fungi was published in two volumes in 1871. For several years previously Cooke had been getting the opinions of Berkeley, Broome and other workers on various specimens. Writing to Broome in 1865 he says: "I may be excused for sending you by this post a marked list of my desiderata, so that at any time, should specimens fall in your way, you will not forget a smoke-dried citizen, whose opportunities for finding them himself are limited."

Cooke had also been publishing his Fungi Britannici Exsiccati since 1865 , and continued to do so until 1879: meanwhile he had arranged the fungi in the British Museum and at the Edinburgh Gardens. The Handbook was an immediate success. The prospectus had asked for subscribers at half-aguinea. "Subscribers will not regret that, instead of 600 pages they will receive more than 900; and instead of 200 figures upwards of 400 ." Non-subscribers were charged twelve shillings a volume!

Berkeley in the English Flora (1836) had rescued the British Fungi from their previous chaos and applied to them the Friesian classification. The number of species he described was I390. In 1860 was published his Outlines of British Fungology. The species in this volume numbered 1450, "but it was so restricted by the publishers as to be of service only to those who possessed the works of Fries and other writers, so far as the more minute forms are concerned, since it contained specific characters of the larger species only, with short descriptions of the families, orders, and genera, accompanied by a list of the remaining species." "The Handbook described $28 \mathrm{ro}$ species. The book is on traditional lines, and is moreover the last complete British Fungus Flora. In the preface

* Review of Handbook by C. E. Broome, Journ. Bot., 1871, p. 312. 
the author says: "Pursuing the study of Fungi as a recreation in the intervals of the daily business of life, it was no easy task to prepare and arrange the descriptions of nearly three thousand plants, compare specimens and figures, and measure their spores." No second edition appeared, "for lack of the necessary leisure," but descriptions of the Hymenomycetes were published (I883-9I) as an appendix to Grevillea. This socalled "second and revised edition" could not compete with Stevenson's British Fungi (1886). Writing a few years later Cooke remarks: "If I may judge from my own experience, it is often the case that the individual has little power to control the direction of his studies after he has once started on his course. My own predilections would be in favour of more exclusively physiological investigations, but finding no systematic arrangement of the British Fungi in existence ten years ago, as the basis of operations, I set myself at first to what I conceived the most essential work, and issued the 'Handbook.' Then, I thought, surely it would be permitted me to pursue some course of investigation; but, on the contrary, the publication of the book increased the number and interest of the workers, and gave such an impetus to British Mycology, that at once I became drawn into and involved in a maze of correspondence, not only in the British Islands, but over Europe and America, with regard to the species contained in this book, and the two thousand soon became three thousand; so that in self-preservation and in self-defence I was driven to the study of allied species in other countries, and now I am so committed, by the study of certain groups of which I have consequently acquired a large experience, that $I$ have no alternative but onwards, or to relinquish the study altogether. . . There is still another reason why I am precluded from absolute physiological studies. Having espoused what might be termed strong conservative views on mycological matters, I feel it my duty to science to resist, not only by words, but by work, the innovations of a modern school of Radicalism which threatened to sweep away all old landmarks, and, by wholesale manufacture of new genera and species on illogical, shifting, and unstable bases, to bring science, in so far as Mycology is concerned, into contempt."*

The publication of the Handbook had another effect. According to W. G. Smith, Hardwicke, who had published much of Cooke's work, resented the omission to offer him this, $t$ and although Cooke felt that "it would scarcely have

* Journ. Quekett Micros. Club. IV., p. 248 (1877).

- It would seem that this was not the only reason for the split. Hardwicke had found an editor who agreed to do the work at half-price; in any case, the paper deteriorated much in value after Cooke resigned. 
been possible to have found a more thorough business man, of a more amiable disposition, prompt, practical, methodical and unassuming," he retired from the editorship of Science Gossip and immediately began the well-known cryptogamic periodical Grevillea, which he conducted for twenty years (1872-1892). He wrote to Broome when Grevillea was about to appear: "Although in London, I work alone, and month after month I never see or speak to any one interested in my own speciality." The paper was at first issued monthly, but after two volumes (by which it had extended "itself at home and abroad so as to attain a circulation exceeding that of any botanical magazine yet emanating from this country") it became a quarterly. Cooke wrote most of it, though he had contributions from the majority of the leading cryptogamists.

In I875 appeared Fungi: their Nature, Infuence, and Uses in the International Scientific Series; Cooke was recommended to the publishers by Berkeley who, unable to undertake the work himself from " multiplicity of engagements" and "uncertain health," acted as editor. French and American editions were issued simultaneously: and the book, which clearly shows his all-round and detailed knowledge, was, according to Cooke, almost his only one which proved a commercial success, something like $£ 300$ coming to him in royalties.

Early in 1875 he wrote to Berkeley: "It seems an endless task to reconcile the species published by different authorities -hence I think it would be a good piece of work if I could publish coloured figures of all the species possible of Peziza, clearing up as much as I can and giving authorities for all the specimens figured." This work he commenced to publish later in the year under the title Mycographia.* It went on until I 879, during which time only the fleshy Discomycetes had been published, 406 coloured figures and descriptions comprising the first volume. Many further figures had been prepared, but the lack of subscribers caused the cessation of publication-" we have laboured for twelve years on mycological publications, and never yet realized the cost of production (leaving remuneration entirely out of the question)." +

In I 875 Rostafinski published a Monograph on the Mycetozoa, and made it inaccessible to the vast majority of those interested in the subject by writing it in Polish. Cooke procured a Polish grammar and dictionary, made out those parts which he considered relevant to this country, and published it in 1877 as the Myxomycetes of Great Britain. The following year appeared Clavis Hymenomycetum, written in collaboration

* Cf. Trans. Brit. Mycol. Soc. IV., p. 404 (1914).

+ Grev. IX., p. I4I (I88I). 
with the French mycologist L. Quélet, in which was given a synopsis in Latin of all known European Hymenomycetes.

During this period Cooke was engaged at the India Museum. Here he prepared lists and catalogues and also wrote papers on subjects connected with economic botany and pharmacy, and in 1873 visited Vienna in charge of the Indian Collection for the Austrian Exhibition.

In 1880 the Museum was dissolved and the entire economicobotanical collections "were unreservedly handed over to the Royal Gardens [Kew], the India Office undertaking to pay all the expenses of removal, to expend a sum not exceeding $£ 2,000$ in an extension of Museum No. I so as to provide the increased space required for the intercalation of a complete set of specimens of Indian vegetable products, to make a grant of $\$ 200$ a year for the efficient maintenance of the Indian collections, and to place at the disposal of the establishment, three days a week for a period of five years, the services of Dr. Cooke, one of the curators of the Museum under the India Office."* The same Kew Report later states that "Dr. Cooke, besides being at hand to give information in respect to any matter connected with the Indian collections lately under his charge, has undertaken the re-arrangement of the collection of Thallophytes in the Herbarium, as well as the duty of reporting upon questions connected with plant-diseases produced by fungoid organisms which are submitted to Kew. Dr. Cooke has at once attacked the arrears of the section of the Herbarium devoted to fungi, which owing to the press of work in keeping the phanerogams and ferns constantly worked up, has been somewhat neglected." Writing to Broome about this time Cooke says: "I am just now so fully pressed by demands upon my time that I have not a spare hour-nor shall I until my work at Kew is in a more forward state."

In I 88I Cooke had a serious attack of paralysis, which stopped his work for six months. He had engaged to write for the S.P.C.K. a popular résumé of Darwin's writings under the title Freaks and Marvels of Plant Life. On his way to the printers with the last half-dozen chapters or so he left the manuscript in a "bus and was unable to recover it_- " the notes and memoranda accumulated during some fifteen years had been incorporated, and the originals destroyed." $\dagger$ Cooke managed to supply the copy by the time stated in his contract, but to do this he had to work at tremendous pressure and broke down under the strain. Writing to Berkeley at the end of the year he says: "As for myself I do very well, so long as I

* Kew Report, pp. 56, 62 (1880).

† Freaks and Marvels of Plant Life, p. 274. 
restrict myself to examination, etc., of the larger fungi, but as soon as I sit down to the microscope or spend an hour or two in continuous writing, my head compels me to desist, and I fancy it must be some considerable time before I shall be able to undertake any continuous microscopic work." In the same year appeared the first part of the work for which Cooke's name will always be famous, the Illustrations of British Fungi. He had long cherished the idea of publishing such a work, and to this end had collected drawings of the rarer species from all the leading British Mycologists. Ten years previously he had written to Broome: "I am going in very extensively for these drawings in the hope of publishing an Atlas to my 'Handbook.'" The work appeared in seventy-six parts and occupied ten years in publication. It contained $\mathrm{I}, 200$ coloured plates and is the largest and most complete work of its kind ever produced. In I 883 Cooke wrote to Broome: "I find that the drawings for my illustrations occupy nearly all my time." He was at one time quite prepared to continue the work and include the whole of the Basidiomycetes, but sufficient subscribers to secure him against pecuniary loss were not forthcoming. It appears from the Broome correspondence that in the early eighties Cooke wished Broome to collaborate with him in getting together all Berkeley's species. "This seems to me to be the best testimony I can offer to Mr. Berkeley at the close of a long and assiduous career" (1 880). When Saccardo's Sylloge was proposed Broome saw that this work was unnecessary. In the light of later events it is interesting to read Cooke's private comments on Saccardo's project of giving a description of all known fungi. "I am very doubtful whether Saccardo's work will at all interfere with what we have projected-I think not. He would have to devote a whole life to it, and hence I doubt it ever being completed. I have not hitherto permitted it at all to interfere with my intentions. I see no reason why it should in the least interfere with a Sylloge Berkeleyanum " (I882). The work was never published.

During these years, although having so much other work, Cooke, in addition to writing popular books on natural history, turned his attention to freshwater algae, but his three publications British Fresh Water Algae (1882-4), British Desmids (I887), and Introduction to Fresh Water Algae (1890), were far from satisfactory. He himself some years afterwards wrote that "the mycologist of to-day, if he would be master of his subject, must give it his undivided attention and be content with riding but one hobby if he would ride well." Notwithstanding their defects the books were of value in stimulating students to further work on these plants. An excellent account of British Edible Fungi appeared in 1891, as well as 
his large Handbook of Australian Fungi. In 1892 he published a popular volume giving a very good account of entomophagous fungi-Vegetable Wasps and Plant Worms. At the end of the year, having reached the age limit ( 65 years), he retired from Kew. "Besides incorporating the considerable accumulations, he rearranged and brought the whole into excellent order. In consideration of his services at Kew, the Secretary of State for India in Council was pleased to make a small addition to his pension."* $\mathrm{He}$ also now gave up the editorship of Grevillea, although he continued to contribute to its pages for the two years during which it continued to appear with Mr. G. Massee as editor.

Cooke continued to write articles in various periodicals. One of his last papers, "What is Hygrophorus Clarkii Berk. \& Br.?" appeared in the Transactions of this Society for the season 1908. His remaining volumes are: Handbook of British Hepaticae (1895), which did not add to his reputation; Introduction to the Study of Fungi (1895), a book on similar lines to his volume of 1872 , and one which would doubtless have achieved a certain amount of success had it not been published (much against Cooke's wishes) at the absurdly high price of fourteen shillings; and Fungoid Pests of Cultivated Plants (1906), an excellent account of plant diseases which had appeared as a series of papers in the Journal of the Royal Horticultural Society. His last work on fungi was a Catalogue and Field-book of British Basidiomycetes (1910). This was "issued as a protest against a recently published alteration of the nomenclature attached to each species." Though advertised as being " in a convenient pocket size and form" its inconvenient size and shape effectively prevented its use in the field. He left a manuscript dealing with Edible and Poisonous British Fungi, illustrated principally from his Illustrations. During this period Cooke, as "Uncle Matt," wrote books on wild flowers for children.

No account of Cooke's career can be considered complete without some reference to his activities in the field. For a number of years he acted as leader at fungus "forays" all over the country. The forays originated with the Woolhope Club. At a meeting in 1867 a Mrs. Key read a paper on Agaricus Georgii. Dr. H. G. Bull, who had then just begun the study of mycology, made some comments on the paper, and after describing the edible qualities of certain species remarked that as the fungi of the neighbourhood seemed excellent he thought the Woolhope Club should make them their special study. The meeting was enthusiastic enough to vote

* Kew Bull., p. 144 (1893). 
$£ 6$, there and then, for the publication of three plates of edible fungi in their Transactions. The following year the Royal Horticultural Society, at the instigation of the Rev. M. J. Berkeley, offered prizes for the best collections of edible fungi. The Woolhope Club gained the first prize, and Mr. W. G. Smith the second. The same autumn an announcement was printed and circulated that an extra field meeting would be held at Hereford "for a Foray amongst the Funguses." Twenty-one persons sat down to dinner at this first foray, which had Messrs. Edwin Lees and W. G. Smith as referees. The scope of the foray, which, at first, was only that of collecting fungi suitable for the dinner, was speedily extended until it included all fungi. The forays continued until 1892 . Dr. H. G. Bull, who had been the prime mover in the affair, died in 1886 , and this, in conjunction with several "lean" seasons, took the life out of this famous meeting. Continental mycologists used to visit Hereford, every British mycologist of those days was a Woolhopean, and as many as sixty at the Green Dragon dinners was no unusual number. Many other clubs and societies copied these excursions to some degree but could not rival them. Cooke appears to have paid his first visit in $187 \mathrm{I}$. His geniality and wit, as well as his special liking for edible fungi, soon made him one of the leading members. He usually read a paper at the meeting; often this was a humorous contribution, and sometimes he indulged in his old habit of verse making. After Bull's death, Cooke became the leading spirit at the forays. "Certainly the establishment of these Forays had something to do with the preparation and publication of the Handbook of British Fungi in 1871 , for at once the necessity for such a work became apparent. Later on it was suggested that some compact volume for field work would be an advantage, and in 1878, the Clavis Hymenomycetum made its appearance. Finally the excellent series of drawings of Fungi which had been made by Dr. Bull prompted the publication of Illustrations of Fungi, which were commenced in $188 \mathrm{I}$ in consequence of the strong recommendation of some of the members of the Woolhope Club."*

During the decline of the Woolhope Club, British Mycologists began to attend the foray of the Yorkshire Naturalists' Union. At the meeting in 1896 , at Selby, the idea of a "National Mycological Union," which had been first formally discussed at Huddersfield in the previous September, $\uparrow$

* Trans. Woolhope Club, p. 67 (1892).

+ The photograph published in this number was taken at the Huddersfield meeting, and gives a characteristic likeness of Cooke and of the first officers of the Society. 


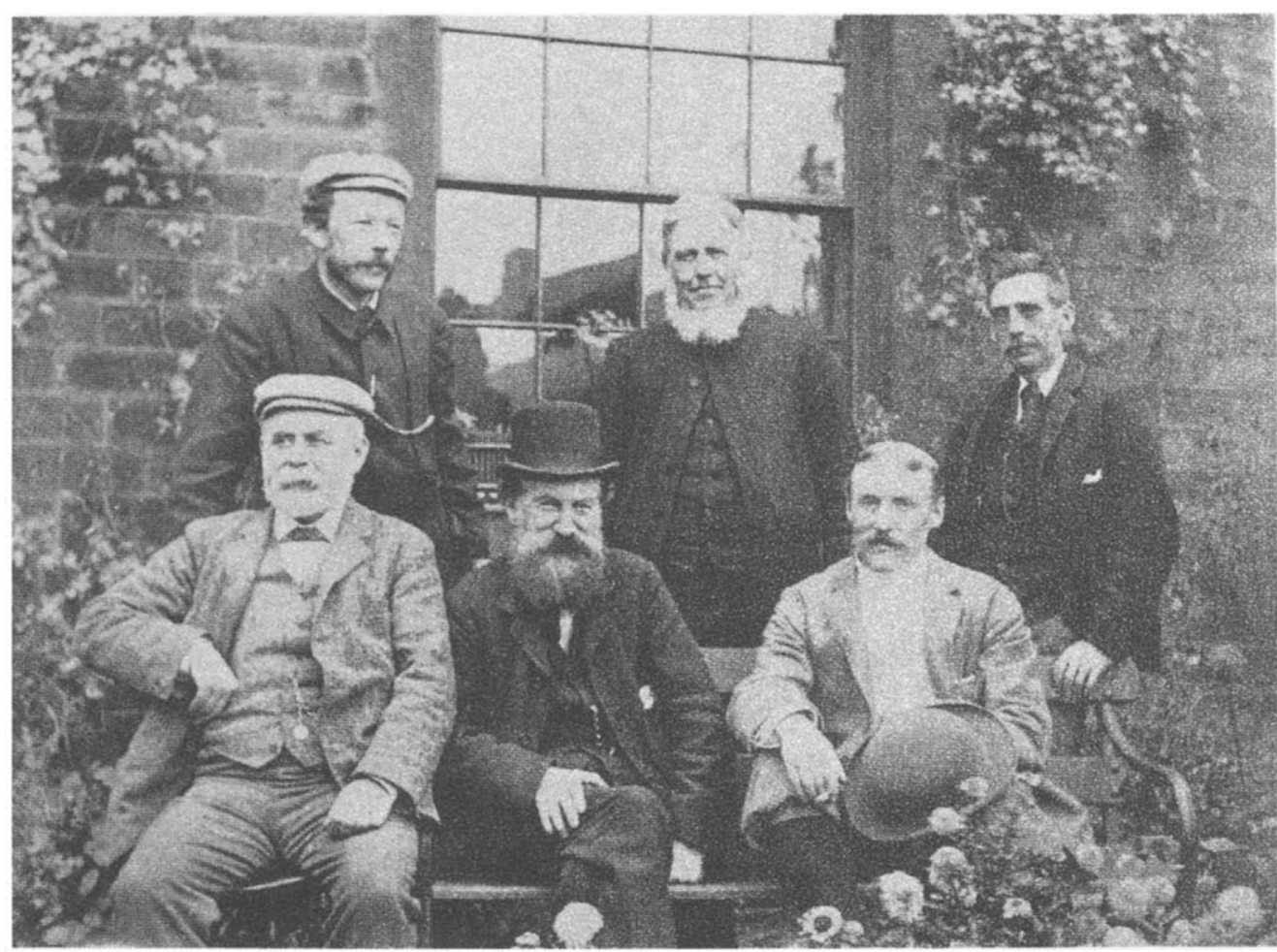

Charles Crossland.

M. C. Cooke.

Carleton Rea. 
took shape, and the British Mycological Society was formed, the want of such a Society being due to the cessation of the Woolhope Foray and the discontinuance of Grevillea.

In the first year there were 48 members. Mr. George Massee was the first President, Mr. Charles Crossland the first Treasurer, and Mr. Carleton Rea the first Secretary. Cooke by this time was too old to take an active part in the Society, though he contributed papers to the Transactions, which more than replaced Grevillea in regard to Fungi and Mycetozoa. Many members have striven hard to place the Society in its proper position, but it is chiefly due to the enthusiasm and energy of Mr. Carleton Rea, who has been secretary since its formation, that it can now show a membership of 138, and a publication that is one of the most important in mycological literature.

In the later years of his life Cooke had serious trouble with his eyes. His health generally was never very good, as he suffered more or less from dyspepsia all his life, and his fondness for patent medicines probably made matters worse. Strange as it may sound, he was not fond of the open air, to which he much preferred a pipe and a book, or a theatre. He was, however, a keen angler. In appearance he was rather slender, with a keen alert look, red hair and beard, and not over careful of his personal appearance. Probably having forgotten his "Struggle for Freedom," he was as conservative in politics as he was in science: in the one he was a prominent member of the Primrose League and in the other he was content to follow the Friesian tradition as expounded by Berkeley, and opposed with all the strength of a vigorous pen the doctrines of lichen symbiosis and heteroecism. "As for my friends, they may rest assured that when I have shuffled off this mortal coil they will be able to say, with confidence, that amidst all my follies and crimes, I was never the advocate of the theories of Table-turning, Tichborne, or Schwendener."* Cooke's increasing blindness, owing to cataract, gradually left him practically helpless. Unable to read, he was still of clear mind, and liked nothing better than that his daughter should read to him popular articles on science when written by authoritative pens. He was particularly interested in those of Sir Ray Lankester, whom he remembered " as a boy in a short Eton jacket" frequenting Hardwicke's shop in company with his father. It is impossible to imagine the sufferings of a man of Cooke's restless energy under such an affliction. He would often write on slips of paper the dates and titles of his more important works, the number of illustrations, etc.-a

\footnotetext{
* Grevillea VII., p. 126 (1879).
} 
craving for the feeling of having once done something, "to look back with proud satisfaction at all of which we have individually been able to do in aid of the onward progress of this department of Natural Science."

A year or two before his death Cooke underwent an experience that would have given him intense amusement in his younger days, but his course was too nearly run for him to look on the lighter side. This was a premature account of his decease.* The interview in the Morning Post on his eightyseventh birthday gave rise to the report of his death, which received currency in a note in the Journal of Botany. The Kew Bulletin (p. 369, 1912) gave a sympathetic account of his career, in which it stated that Cooke's "attention was soon attracted to fungi, at first from an edible standpoint, but soon, as Cooke himself often stated, the fungi exercised such a spell over his entire existence, that his interest in these plants ceased only when he peacefully passed away at his residence in Kentish Town on August Igth, a few days after his 87 th birthday." Cooke strenuously denied his death, stating it to be "somewhat premature, as I am still alive and lively."

His strength began to fail now at an increased rate. In January, 1914, he left London and went to live with a married daughter at East Southsea. At first he was much better for the change, but after a time heart attacks set in, and he succumbed to old age on November I2th; he was buried at Finchley on November I 7 th.

In Lindau and Sydow's Thesaurus there are some 350 references to Cooke's notes, papers and books. These concern every section of the fungi. His herbarium of 46,000 specimens was purchased in 1887 by $\mathrm{Kew}$, where is also his collection of drawings, computed by the Kew authorities to number 22,000, of which, according to Cooke, 6,000 are original.

Cooke received many honours. Having done much for American mycology, he received the honorary degrees of M.A. (St. Lawrence 1870, Yale 1873) and L.L.D. (New York 1874), and was made honorary member of many American societies. In this country he was elected Associate of the Linnaean Society in 1877 , and received the Linnaean Gold Medal in 1903. He was made V.M.H. in 1902, and was an honorary member of most of the British Natural History Societies. He was also honorary member of the Société Mycologique de France.

Cooke had a greater influence on the study of fungi than any other Englishman with the possible exception of Berkeley.

* This does not appear to have been his only experience of such a fate, as in a letter to him, dated 1864 (now in the Department of Botany, British Museum), occurs the following sentence: "I am glad to hear you are alive, I having heard from several parties that you were dead." 
Much of his work, it must be admitted, was somewhat slipshod and much of it "scissors and paste." But his Handbook, Illustrations, Mycographia, and Grevillea, together with his efforts to popularize the study of fungi, enable us to realize his place in Mycology.

I am indebted to Miss Leila A. Cooke for her kind assistance in many ways.

\section{WILLLIAM LEIGH WILLIAMSON EYRE.}

$$
\begin{gathered}
(184 \mathrm{I}-1914 .) \\
\text { By J. Ramsbottom, M.A. }
\end{gathered}
$$

The British Mycological Society has suffered a great loss through the death, on October 25 th, I9I4, of the Rev. W. L. W. Eyre, one of its most loyal members. Mr. Eyre was born at Padbury, Bucks, on March I 7 th, I841. Educated for the merchant service, he went to sea at an early age, but gave up sea-faring to enter Lichfield College as a theological student. He was ordained deacon in 1865 and priest in 1866 , in Lichfield Diocese. His first curacy was at Sheriff Hales, Staffordshire, 1865-8. Afterwards he was curate of West Dean, Wilts., I868-70; of Huntley, Gloucester, I870-72; and Northchurch, Hertfordshire, $1872-5$. In 1875 he was appointed rector of Swarraton and vicar of Northington, Hants, by the then Lord Ashburton. Mr. Eyre early took up the study of fungi, and was a member of the Woolhope Club during the later years of its mycological activities. When the British Mycological Society was formed in 1896 , he at once became one of its most enthusiastic members, and up to the time of his death took the greatest possible interest in everything that affected the Society. For a number of years he most generously provided the Transactions with a coloured plate, realising the great necessity of such in the study of Basidiomycetes. For the season I 903 he was elected President, and gave as his address "Mycology as an instrument of recreation." The only other paper he wrote for the Transactions is "Notes on Hants Fungi" (1899), a most suggestive paper giving his experiences as to the relation of certain fungi to edaphic conditions. $\mathrm{He}$ was responsible for the list of Hampshire fungi in the Victoria County History, and in 1907 published " A list of the fungi of the Grange Park and neighbourhood, Hampshire." The repu- 